\title{
Management of twin pregnancy with a hydatidiform mole and surviving healthy co-existent fetus
}

\author{
Hale Göksever Çelik ${ }^{1 *}$, Gözde Meriç Demirezen ${ }^{1}$, Baki Erdem², \\ Alev Atiş Aydin', Volkan Ülker²
}

\begin{abstract}
${ }^{1}$ Department of Obstetrics and Gynecology, ${ }^{2}$ Department of Gynecologic Oncology, Saglik Bilimleri University, Kanuni Sultan Suleyman Training and Research Hospital, Istanbul, Turkey
\end{abstract}

Received: 17 September 2017

Accepted: 27 October 2017

\section{*Correspondence:}

Dr. Hale Göksever Çelik,

E-mail: hgoksever@yahoo.com

Copyright: (c) the author(s), publisher and licensee Medip Academy. This is an open-access article distributed under the terms of the Creative Commons Attribution Non-Commercial License, which permits unrestricted non-commercial use, distribution, and reproduction in any medium, provided the original work is properly cited.

\begin{abstract}
Twin pregnancies with complete mole and a coexisting live fetus are rare obstetric conditions seen in 1 case of 22000 to 100000 pregnancies. In our case, a twin molar pregnancy was diagnosed in the first trimester by ultrasound. In a 27-year-old patient with the first pregnancy, a 12-week live fetus with a normal placenta and a twin molar pregnancy appearance were observed on a routine ultrasonographic examination of the uterine cavity. Twin molar pregnancies are reported to be terminated by live birth in the literature, but termination of pregnancy is an important option to prevent maternal morbidity since molar pregnancy may lead to complications ranging from theca lutein cysts to gestational trophoblastic neoplasia.
\end{abstract}

Keywords: Gestational trophoblastic disease (GTD), Hydatiform mole, Twin pregnancy

\section{INTRODUCTION}

Twin pregnancies with complete mole and a coexisting live fetus are rare obstetric conditions seen in 1 case of 22000 to 100000 pregnancies. $^{1}$ In present case, a twin molar pregnancy was diagnosed in the first trimester by ultrasound. Close follow-up is an option in the management of these pregnancies. However, termination is another alternative that could be offered to these families because of related risks and complications. ${ }^{2}$

\section{CASE REPORT}

In a 27-year-old patient with the first pregnancy, a 12week live fetus with a normal placenta and a twin molar pregnancy appearance were observed on a routine ultrasonographic examination of the uterine cavity (Figure 1). On admission, her vital signs were normal. Her laboratory studies showed hemoglobin level $12 \mathrm{~g} / \mathrm{L}$, hematocrit level 34\%, beta hCG level $606104 \mathrm{mIU} / \mathrm{ml}$, TSH level 0,078 $\mu \mathrm{IU} / \mathrm{mL}$, free triiodothyronin level 4,49 $\mathrm{pg} / \mathrm{mL}$, free thyroxin level $1,76 \mathrm{pg} / \mathrm{mL}$. Her chest X-ray was also normal. The gestational trophoblastic disease and related risks were explained and termination as an option for management was offered. The written informed consent was taken from the woman and her husband who preferred termination. Then vaginal prostoglandin E2 was applied to the patient for cervical dilatation before the curettage according to International Federation of Gynecology and Obstetrics (FIGO) guidelines. After 2 hours, the vacuum curettage was performed in lithotomy position under general anesthesia.

Vesicles that were characteristic for molar pregnancy were observed in curettage material. All extracted samples were sent to the Pathology department for examination. After curettage, infusion of intravenous fluid with 30 units of oxytocin was applied. 


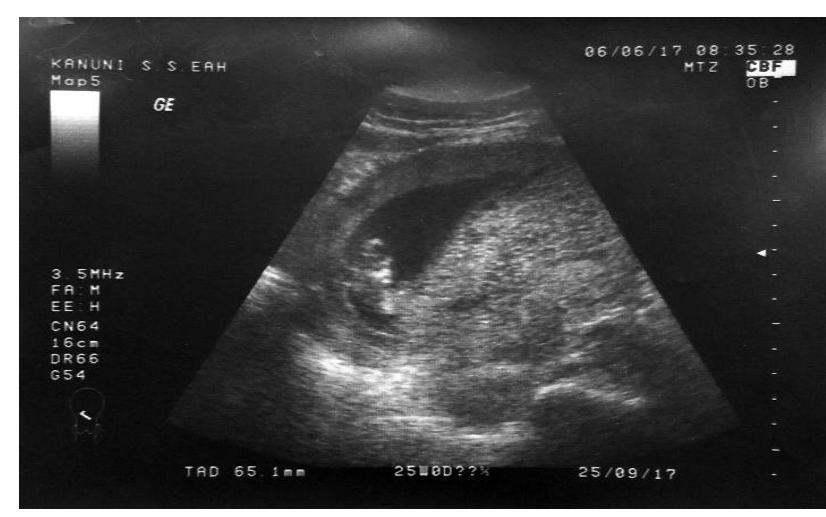

Figure 1: Ultrasonographic examination of the uterine cavity.

Two units of red blood cell were transfused because her postoperative hemoglobin level was $7,5 \mathrm{~g} / \mathrm{L}$ and hematocrit level was $21.7 \%$. After the transfusion, hemoglobin and hematocrit levels were increased to 10,5 $\mathrm{g} / \mathrm{L}$ and $29,3 \%$, respectively. On postoperative $1^{\text {st }}$ day, beta hCG level decreased to $164734 \mathrm{mIU} / \mathrm{mL}$. The patient was discharged and called to the outpatient gynecologic oncology clinics. After 10 days beta hCG level was $7538 \mathrm{mIU} / \mathrm{mL}$ on the $1^{\text {st }}$ control and after 18 days its level was $1373 \mathrm{mIU} / \mathrm{mL}$ on the $2^{\text {nd }}$ control and after 25 days its level was $364 \mathrm{mIU} / \mathrm{mL}$. The patients are still in follow-up by the gynecologic oncology clinics.

\section{DISCUSSION}

Molar pregnancy is a subgroup of gestational trophoblastic disease which has origin from the placenta and a potential for uterine invasion and metastasis to another organs. Hydatidiform mole is divided into complete hydatidiform and partial hydatidiform. These are different regarding chromosomal patterns, histopathological and clinical characteristics. Molar pregnancies areaccepted as premalign even if they are benign because they have potential for malignant development. Complete molar pregnancies are diploid, partial molar pregnancies are triploid. ${ }^{3}$

Multiple pregnancies can also be complicated with complete or partial hydatidiform molar pregnancy and a live fetus. Twin pregnancies with complete mole and a coexisting live fetus are rare obstetric conditions seen in 1 case of 22000 to 100000 pregnancies. The increased incidence of such pregnancies is possible because use of ovulation induction in older women and incidence of multiple pregnancies are rising. Multiple pregnancies containing hydatidiform mole can usually be detected by ultrasound, but occasionally amniocentesis and chromosome analysis is required. ${ }^{4}$ Patients should be informed about potential risks such as bleeding, thyrotoxicosis and thyroid crisis, preeclampsia, preterm birth, gestational trophoblastic neoplasia (GTN). ${ }^{5}$ It is stated that twin molar pregnancies can be terminated by live birth in the literature. In addition, counseling should be done on the increased risk of some medical complications, such as perforation, during termination of treatment. ${ }^{6,7}$ It should be known that the follow-up of the patients is important after the curettage procedure and it should be explained that the serial beta hCG values should be checked and follow-up to the gynecological oncology outpatient clinics should be done for the clinical examinations. $^{8}$

Funding: No funding sources

Conflict of interest: None declared

Ethical approval: Not required

\section{REFERENCES}

1. Suksai M, Suwanrath C, Kor-Anantakul O, Geater A, Hanprasertpong T, Atjimakul $\mathrm{T}$ et al. Complete hydatidiform mole with co-existing fetus: Predictors of live birth. Eur J Obstet Gynecol Reprod Biol. 2017;212:1-8.

2. Vimercati A, de Gennaro AC, Cobuzzi I, Grasso S, Abruzzese M, Fascilla FD, et al. Two cases of complete hydatidiform mole and coexistent live fetus. J Prenat Med. 2013;7(1):1-4.

3. Peng HH, Huang KG, Chueh HY, Adlan AS, Chang SD, Lee CL. Term delivery of a complete hydatidiform mole with a coexisting living fetus followed by successful treatment of maternal metastatic gestational trophoblastic disease. Taiwan J Obstet Gynecol. 2014;53(3):397-400.

4. Piura B, Rabinovich A, Hershkovitz R, Maor E, Mazor M. Twin pregnancy with a complete hydatidiform mole and surviving co-existent fetus. Arch Gynecol Obstet. 2008;278(4):377-82.

5. Kutuk MS, Ozgun MT, Dolanbay M, Batukan C, Uludag S, Basbug M. Sonographic Findings and Perinatal Outcome of Multiple Pregnancies Associating a Complete Hydatiform Mole and a Live Fetus: A Case Series. J Clin Ultrasound. 2014;42(8):465-71.

6. Lin LH, Maesta I, Braga A, Sun SY, Fushida K, Francisco RPV et al. Multiple pregnancies with completemole and coexisting normal fetus in North and South America: A retrospective multicenter cohort and literature review. Gynecol Oncol. 2017;145:88-95.

7. Rohilla M, Singh P, Kaur J, Jain V, Gupta N, Prasad GRV. Individualistic approach to the management of complete hydatidiform mole with coexisting live fetus. Eur J Obstet Gynecol Reprod Biol. 2015;191:39-42.

8. Bruchim I, Kidron D, Amiel A, Altaras M, Fejgin MD. Complete hydatidiform mole and a coexistent viable fetus: report of two cases and review of the literature. Gynecol Oncol. 2000;77:197-202.

Cite this article as: Çelik HG, Demirezen GM, Erdem B, Aydin AA, Ülker V. Management of twin pregnancy with a hydatidiform mole and surviving healthy co-existent fetus. Int J Reprod Contracept Obstet Gynecol 2017;6:5636-7. 